\title{
Detection of Thyrotropin Binding Inhibitory Activity in Neonatal Blood Spots*
}

\author{
ROSALIND S. BROWN, RONALD L. BELLISARIO, ELIZABETH MITCHELL, \\ PAULA KEATING, AND DIEGO BOTERO \\ Department of Pediatrics, University of Massachusetts Medical School (R.S.B., E.M., P.K., and D.B.), \\ Worcester, Massachusetts 01655; and the Wadsworth Center for Laboratories and Research, State of New \\ York Department of Health (R.L.B.), Albany, New York 12201
}

\begin{abstract}
Recent studies have suggested that maternal TSH receptor-blocking antibodies might be of primary etiological importance in some cases of transient congenital hypothyroidism $(\mathrm{CH})$. Because these antibodies are extremely potent, we evaluated the feasibility of identifying babies at risk by using readily available newborn blood spots. Blood spots obtained from 84 normal babies (group 1) and from 354 infants whose initial $T$, was less than the tenth percentile for the assay and whose TSH was $40 \mathrm{mU} / \mathrm{L}$ or more (group 2) were studied without knowledge of the diagnosis. Blood was eluted from spots overnight and evaluated for $\left.{ }^{125} \mathrm{I}\right] \mathrm{TSH}$ binding inhibition (TBI) to solubilized porcine thyroid membranes. Four spots obtained from 3 group 2 babies, but none of those from the group 1 infants, exhibited TBI activity greater than 3
\end{abstract}

SD above the normal mean (33.9\%). Four additional hypothyroxinemic infants whose mothers had Graves' disease were also negative. Subsequent follow-up revealed that all 3 positive babies had transient $\mathrm{CH}$, and all 3 mothers had primary myxedema. Potent TBI activity was confirmed in the serum of all 3 mothers and in the 2 babies in whom it was evaluated at birth.

We conclude that newborn blood spots can be used to detect potent maternal TBI activity, and that this identifies a baby likely to have transient, rather than permanent, $\mathrm{CH}$. Because of their stability and ease of collection and handling, newborn blood spots should offer a convenient tool for future studies aimed at defining in more detail the incidence and clinical characteristics of this unique syndrome. $(J \mathrm{Clin}$ Endocrinol Metab 77: 1005-1008, 1993)
A SYNDROME of transient congenital hypothyroidism (CH) has been described in babies born to mothers with autoimmune thyroid disease and potent TSH receptorblocking antibodies in serum (1-3). Infants with this disorder are indistinguishable at birth from those with thyroid dysgenesis, because they frequently have severe hypothyroidism, no goiter is palpable either in the baby or mother, and thyroid uptake is significantly reduced or absent $(4,5)$. Unlike sporadic thyroid dysgenesis, however, babies with blocking antibody-induced $\mathrm{CH}$ tend to have transient disease, and the disorder has a high recurrence rate in subsequent offspring due to the tendency of these antibodies to remain elevated for a long time in maternal serum (1-5).

The prevalence of TSH receptor-blocking antibodies as a cause of $\mathrm{CH}$ is unknown. Because only those babies born to mothers with the most potent blocking antibodies develop hypothyroidism $(3,6-8)$ and the binding inhibitory effect correlates well with inhibition of TSH-induced stimulation of thyroid growth and function $(6,9,10)$, we hypothesized that it might be possible to screen for TSH receptor-blocking antibodies by evaluating TSH binding inhibition (TBI) using

Received February 8, 1993. Accepted June 1, 1993.

Address all correspondence and requests for reprints to: Rosalind S. Brown, M.D., Department of Pediatrics, University of Massachusetts Medical Center, 55 Lake Avenue North, Worcester, Massachusetts 01655.

- This work was supported in part by Clinical Research Grant 6-492 from the March of Dimes Birth Defects Foundation and Boots Pharmaceuticals, Inc. Portions of this work have been presented at the 64th Annual Meeting of the American Thyroid Association, San Francisco, CA, September 6-9, 1989, and at the 20th Annual Meeting of the European Thyroid Association, Dublin, Ireland, June 20-25, 1992. readily available newborn blood spots. The present studies were performed to evaluate the feasibility of this method.

\section{Materials and Methods}

\section{Study population}

Serum was initially obtained from two patients with known primary myxedema $\left(1^{\circ} \mathrm{M}\right)$ and two normal individuals for use in the pilot studies to be described. Patient 1 has had two babies with transient $\mathrm{CH}$, and her immunoglobulin $\mathrm{G}(\mathrm{IgG})$ results have been previously reported (10). Patient 2 was a 10 -yr-old girl who presented with severe $1^{\circ} \mathrm{M}$ and was known to have TSH binding inhibitory IgG of intermediate potency.

Blood spots were obtained from the New York State Hypothyroid Screening Program between 1987 and 1988 and included 84 blood spots from normal babies (group 1) as well as 465 samples from 354 infants whose initial $\mathrm{T}_{4}$ was less than the tenth percentile for the assay and whose TSH was greater than or equal to $40 \mathrm{mU} / \mathrm{L}$ (group 2). Of the group 2 babies, 150 were considered to have confirmed $\mathrm{CH}$ because their TSH levels had remained elevated on retesting. In the remaining 204 unconfirmed babies, thyroid function tests were normal on repeat exam. This miscellaneous patient group included babies with borderline values and those who had been screened before 4 days of age because of early discharge. As an additional control, 4 spots obtained from hypothyroxinemic infants whose mothers had Graves' disease were studied as well. All spots had been stored desiccated at $-4 \mathrm{C}$ and were studied without knowledge of the diagnosis.

The study protocol was approved by the Committee on the Protection of Human Subjects in Research at the University of Massachusetts Medical Center.

\section{Methods}

In the initial studies, dried blood spots were prepared by mixing washed cells from normal heparinized blood with serum containing the desired test hormone or IgG in a ratio of 1:1, spotting the mixture onto 
filter paper, and allowing the blood to dry for at least $18 \mathrm{~h}$. Disks were punched using a standard 1/8th-in. paper punch and incubated in 200 $\mu \mathrm{L} 50 \%$ Coon's Modified Ham's F-12 culture medium overnight at $4 \mathrm{C}$. Fifty microliters of eluted blood were then assayed for $\left.{ }^{125} \mathrm{I}\right]$ bovine TSH (bTSH) binding inhibitory (TBI) activity according to the method of Southgate et al. (11). Each sample was studied in duplicate. The assay used Triton $X-100$-solubilized porcine thyroid membranes and receptorpurified bTSH, kindly supplied by Dr. John Pierce, University of California-Los Angeles, as tracer. In a few of the preliminary studies, a commercial kit (Kalibre TSH Receptor Antibody, Kronus, Dana Point, CA) was used. Both methods gave equivalent results. Human pituitary TSH (NIDDK hTSH-1-6) was provided by the National Hormone and Pituitary Program; recombinant human TSH (Genzyme) was the gift from Dr. Lewis Braverman.

Results were corrected for nonsaturable binding, and the percent inhibition of $\left[{ }^{125} \mathrm{I}\right] \mathrm{bTSH}$ binding was expressed as a TBI index, computed as follows: 1 - (specific binding of $\left[{ }^{125} \mathrm{I}\right] \mathrm{bTSH}$ in the presence of test sample/specific binding of $\left[{ }^{125} \mathrm{I}\right] \mathrm{bTSH}$ in presence of control samples) $\times$ 100; unknowns were compared with the mean value of 6-10 normal spots evaluated in the same assay.

All spots were studied in duplicate. Any spot with a result $1.75 \mathrm{sD}$ greater than the normal mean or higher was repeated.

\section{Results}

\section{Pilot studies}

Initial studies demonstrated that the TBI activity of blood spots obtained from the two $1^{\circ} \mathrm{M}$ patients whose IgG was known to have strong and intermediate potency, respectively, could be clearly distinguished from normal, and that the previously identified relative difference in potency could be demonstrated (Fig. 1). A dose-response curve was observed; potency was dependent on the number of filter paper disks used for elution. From these results, elution of four blood spot disks was selected for routine assay, as TBI activity was readily detectable with this quantity of blood and this amount of blood was obtainable from the majority of spots. Initial studies indicated that elution with either $50 \%$ Coon's F-12 or $10 \mathrm{mmol} / \mathrm{L}$ Tris $-50 \mathrm{mmol} / \mathrm{L} \mathrm{NaCl}$ gave equivalent results, and both were superior to $20 \%$ sucrose. Elution with

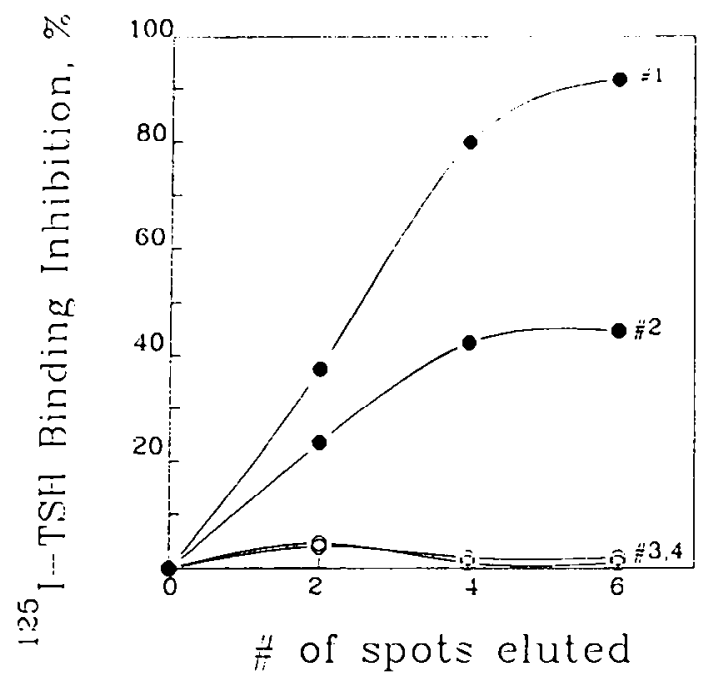

FIG. 1. Inhibition of $\left[{ }^{125} \mathrm{I}\right] \mathrm{TSH}$ binding by two patients with primary myxedema $(O)$ and two control individuals $(O)$. Results with eluted blood mirrored known TBI activity in serum and were dose dependent; inhibition was dependent on the number of spots eluted.
$2 \mathrm{~mol} / \mathrm{L} \mathrm{NaCl}$ completely blocked $\left[{ }^{125} \mathrm{I}\right] \mathrm{bTSH}$ binding of both normal and $1^{\circ} \mathrm{M}$ samples (results not shown). For the studies to be described, $50 \%$ Coon's F-12 medium was used.

Because the infants to be studied were expected to be hypothyroid, experiments were performed to evaluate the possible cross-reactivity of human TSH in this heterologous RRA. In three separate experiments, $1 \mathrm{U} / \mathrm{L}$ human pituitary TSH added to serum produced only $17.6 \pm 7.7 \%$ (mean \pm SEM) inhibition of $\left[{ }^{125} \mathrm{I}\right] \mathrm{bTSH}$ binding. Results with recombinant hTSH were similar and are shown in Fig. 2. When added to blood, spotted onto filter paper, and eluted, as much as $2 \mathrm{U} / \mathrm{L}$ hTSH, the highest concentration tested, did not produce significant inhibition of tracer binding.

\section{$T B I$ activity in blood spots}

The TBI activity of 84 blood spots obtained from 84 normal babies (group 1) and 465 blood spots obtained from 354 infants with either confirmed $(n=150)$ or unconfirmed $(n=$ 204) $\mathrm{CH}$ (group 2) was studied (Fig. 3). The mean blood spot TBI activity in normal babies was $0.9 \pm 11.0 \%$ (mean \pm SD). Four spots obtained from 3 group 2 babies had TBI activity greater than $3 \mathrm{SD}$ above the normal mean $(61.4 \%, 71.9 \%$, $41.7 \%$, and $54 \%$, respectively) and remained positive on retesting $(60.2 \%, 40.9 \%, 48.1 \%$, and $58.0 \%$, respectively). All 3 babies had confirmed $\mathrm{CH}$. Two other normal spots and 8 other $\mathrm{CH}$ spots had activity greater than 2 SD above the normal mean on initial testing, but these results were not confirmed. No borderline spots, defined as $1.75-2.0 \mathrm{SD}$ greater than the mean, were positive on retesting. The interassay coefficient of variation of a positive control (patient 1) studied in 8 assays was $26.7 \%$; the intrassay coefficient of variation of this sample was $12.0 \%$.

As thyroid-stimulating antibodies in patients with Graves' disease could conceivably inhibit TSH binding and be de-

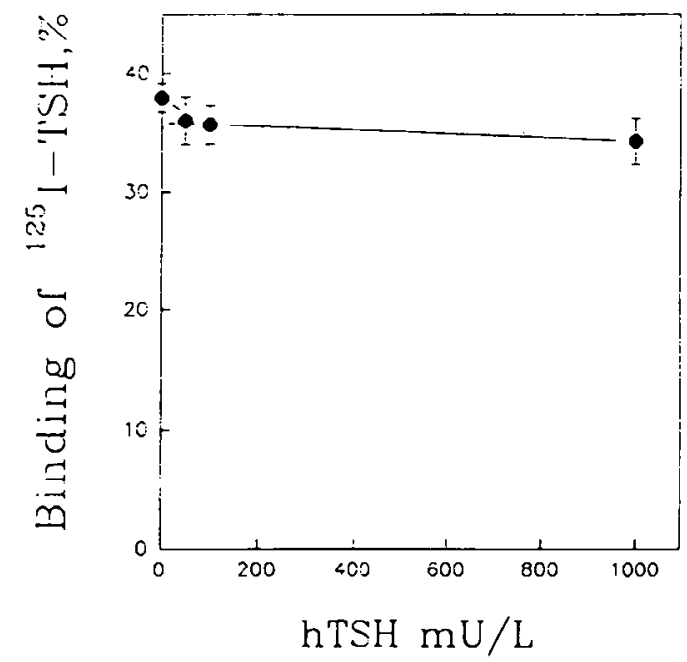

FIG. 2. $\left.{ }^{125} \mathrm{I}\right] \mathrm{TSH}$ binding in the presence of increasing amounts of unlabeled recombinant hTSH in serum. hTSH in amounts up to 1000 $\mathrm{mU} / \mathrm{L}$ resulted in only slight inhibition of $\left[^{125} \mathrm{I}\right] \mathrm{TSH}$ binding. When added to blood and eluted from spots, as much as $2000 \mathrm{mU} / \mathrm{L}$, the highest concentration tested, was similarly without a significant effect. Equivalent results were obtained with a purified pituitary TSH preparation (NIDDK hTSH-1-6). 


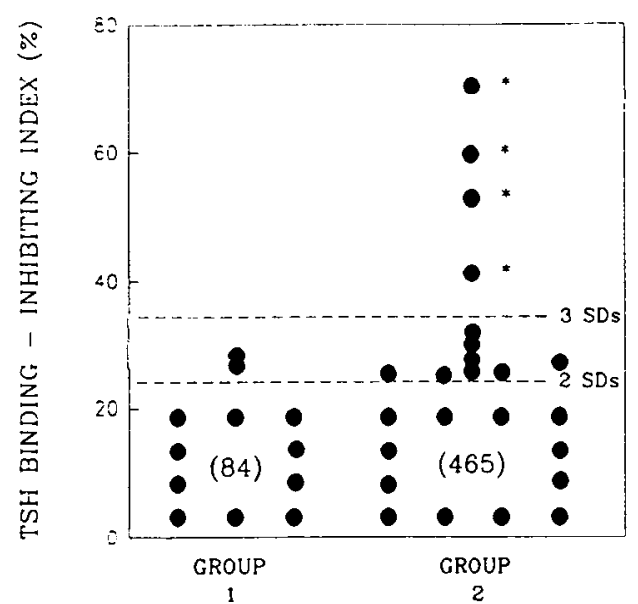

FIG. 3. TBI activity in 84 blood spots from 84 normal babies (group 1) and 465 spots from 354 infants whose initial $\mathrm{T}_{4}$ was in the lowest tenth percentile for the assay and whose TSH was $40 \mathrm{mU} / \mathrm{L}$ or more (group 2). Four spots $\left(^{*}\right)$ obtained from 3 group 2 babies, but none from group 1 infants, exhibited TBI activity greater than 3 SD above the normal mean. Four hypothyroxinemic babies of mothers with Graves' disease were also studied and were negative (data not shown).

TABLE 1. Clinical and laboratory data of three infants with significant TBI-positive activity in blood spots and in their mothers

\begin{tabular}{|c|c|c|c|c|}
\hline \multirow{2}{*}{$\begin{array}{l}\text { Spot } \\
\text { no. }\end{array}$} & \multicolumn{2}{|c|}{ Infant } & \multicolumn{2}{|c|}{ Mother } \\
\hline & Clinical course & $\begin{array}{l}\text { \% TBII } \\
\text { (serum) }\end{array}$ & Diagnosis & $\begin{array}{c}\text { \%TBII/TRAb } \\
\text { (serum) }\end{array}$ \\
\hline 157 & Transient $\mathrm{CH}$ & 89.1 & $1^{\circ} \mathbf{M}$ & $85.5 /-$ \\
\hline 394 & Transient $\mathrm{CH}$ & 82.8 & $\begin{array}{l}1^{\circ} \mathbf{M} \\
\text { (S/P Graves') }\end{array}$ & $77.4 /$ \\
\hline 320 & Transient $\mathrm{CH}$ & ND & $1^{\circ} \mathbf{M}$ & $-/ 382 \mathrm{U} / \mathrm{L}$ \\
\hline
\end{tabular}

TBII, TSH binding inhibitory Ig, determined at Nicholls Institute (San Juan Capistrano, CA; normal value, $<10 \%$ ). TRAb, TSH receptor antibody; this assay, similar to the TBII assay, is based on the method of Southgate et al. (11) (normal value, $<10 \mathrm{U} / \mathrm{L}$ ) and was performed using a commercial kit (Kalibre, Kronus). ND, Not done.

tected in the assay, four blood spots from hypothyroxinemic babies born to mothers with Graves' disease were evaluated as well. No significant TBI activity was observed.

\section{Confirmatory studies}

Clinical and laboratory data concerning the three TBIpositive babies and their mothers, obtained subsequently, are shown in Table 1 . All babies had transient $\mathrm{CH}$, and TSH binding inhibitory activity in serum was confirmed in the two in whom it was tested at birth. All three mothers had $1^{\circ} \mathrm{M}$, and potent TBI activity was present in serum. In one of the mothers, hypothyroidism was preceded by severe Graves' disease treated with radioactive iodine. It is of interest that antimicrosomal [thyroid peroxidase (TPO)] antibodies were positive in two of the three mothers and negative in the third (data not shown).

\section{Discussion}

Although the possibility of a maternal thyrocytotxic factor responsible for some cases of $\mathrm{CH}$ was suggested by Blizzard et al. as early as 1960 (12), it was not until 1980 that Matsuura et al. (1) first described two babies with transient nongoitrous $\mathrm{CH}$ born to a mother with $1^{\circ} \mathrm{M}$ and demonstrated an IgG in maternal serum that inhibited TSH binding and TSH-induced stimulation of thyroid membrane adenyl cyclase. Since that time, numerous such cases have been described, and strong evidence has been gathered to confirm that the thyrocytotoxic factor in these patients is an antibody to the TSH receptor. For example, the blocking activity inhibits TSH binding to both the native porcine $(4,10)$ and human $(1,2$, 6) TSH receptor as well as to the recombinant human (13, $14)$ and murine (15) ones. It interferes only with stimulation by $\operatorname{TSH}(2,3,6)$ or the thyroid-stimulating IgGs of Graves' disease patients $(9,16)$, but not with that induced by postreceptor processes $(9,17)$, except in rare instances $(18)$. The blocking activity is associated with the IgG fraction of serum, because it can be absorbed by and eluted from staphylococcal protein-A affinity columns that specifically bind subclasses 1,2 , and 4 of $\operatorname{IgG}(10,17)$. An etiological role is suggested by the relationship between the severity of the neonatal disease and the putency of the in vitro thyroid-blocking activity (3) and by the tendency for the neonatal hypothyroidism to parallel the disappearance of maternal IgG from the baby's serum (2).

We took advantage of previous studies demonstrating that, analagous to neonatal hyperthyroidism in infants of mothers with Graves' disease (19), only babies born to mothers with the most potent TSH receptor-blocking activity become hypothyroid. As $1.5 \mu \mathrm{L}$ serum were eluted from each of four $1 / 8$ th-in. disks (20), and a volume of $200 \mu \mathrm{L}$ buffer was used for elution, the actual dilution being tested in the present study was $4 \times 1.5: 200$ or 1:33. Our findings, thus, correlate remarkably well with those of previous studies, which demonstrated that half-maximal TBI activity in babies of $1^{\circ} \mathrm{M}$ mothers who became hypothyroid was obtained with a 1:30 to 1:50 dilution of serum. Four spots obtained from three babies exhibited the most potent ( $>3 \mathrm{sD}$ ) blocking activity, and all three babies had transient hypothyroidism. All were in the confirmed $\mathrm{CH}$ group; in contrast, no spots in the 84 normal subjects or 204 unconfirmed $\mathrm{CH}$ babies exhibited TBI activity of this magnitude. Preliminary studies indicated that a serum concentration of hTSH such as might occur in a baby with $\mathrm{CH}$ did not interfere significantly with $\left[{ }^{125} \mathrm{I}\right] \mathrm{bTSH}$ binding, and that results using eluted blood from blood spots were dose dependent and mirrored results using serum.

The presence of potent TSH receptor-blocking antibodies was confirmed in the serum of all three mothers and in the two babies evaluated at birth. Similar to previously reported cases, all three mothers had $1^{\circ} \mathrm{M}$; in one patient, hypothyroidism was preceded by radioactive iodine therapy for severe Graves' disease. It is of interest that TPO antibodies, commonly used as a marker of autoimmune thyroid disease, were present in just two of the three mothers identified. This is consistent with previous reports suggesting that measurement of TPO antibodies is not an adequate screen for the prediction of transient $\mathrm{CH}(10)$.

Because bioactivity was not evaluated specifically, screening for TBI activity could conceivably have identified babies 
of mothers with Graves' disease and high titers of thyroidstimulating antibodies or even those with a mixture of TSH receptor antibodies of varying bioactivity (21). For this reason, spots obtained from four known hypothyroxinemic infants of Graves' disease mothers were studied as well; none contained significant TBI activity. These results suggest that the hypothyroxinemia observed in such babies, therefore, is more likely to be due to maternal thiouracil therapy (22). It is of interest that studies from several laboratories have demonstrated that stimulating antibodies do not inhibit as well as blocking antibodies $(8,13)$, probably because they interact at a different domain on the receptor $(14,15)$.

We conclude that newborn blood spots can be used to detect potent maternal TBI activity, and that this identifies a baby likely to have transient, rather than permanent, hypothyroidism. Because of their stability and the ease of collection and handling, newborn blood spots should offer a convenient tool for future studies aimed at defining in more detail the incidence and clinical characteristics of this unique syndrome.

\section{Acknowledgments}

Drs. Robert Klein and Marvin Mitchell, New England Congenital Hypothyroidism Collaborative, provided the blood spots from two of the hypothyroxinemic babies born to mothers with Graves' disease.

\section{References}

1. Matsuura N, Yamada Y, Nohara Y, et al. 1980 Familial neonatal transient hypothyroidism due to maternal TSH-binding inhibitor immunoglobulins. N Engl J Med. 303:738-741.

2. Iseki M, Shimizu M, Oikawa T, et al. 1983 Sequential serum measurements of thyrotropin binding inhibitor immunoglobulin $\mathrm{G}$ in transient familial neonatal hypothyroidism. J Clin Endocrinol Metab. 57:384-387.

3. Konishi J, lida Y, Kasagi K, et al. 1985 Primary myxedema with thyrotropin-binding inhibitor immunoglobulins. Ann Intern Med. 103:26-31.

4. Connors MH, Styne DM. 1986 Transient neonatal "athyreosis" resulting from thyrotropin-binding inhibitory immunoglobulins. Pediatrics. 78:287-290.

5. Francis G, Riley W. 1987 Congenital familial transient hypothyroidism secondary to transplacental thyrotropin-blocking autoantibodies. Am J Dis Child. 141:1081-1083.

6. Arikawa K, Ichikawa $Y$, Yoshida $T$, et al. 1985 Blocking type antithyrotropin receptor antibody in patients with nongoitrous hypothyroidism: its incidence and characteristics of action. J Clin Endocrinol Metab. 60:953-959.

7. Inomata $H$, Sasaki N, Tamaru $K$, Ushiku H, Niimi $H$, Nakajima H. 1986 Relationship between potency of blocking type thyrotropinbinding inhibitor immunoglobulin in three women with primary myxedema and thyroid function of their neonates. Endocrinol Jpn. 33:353-359.

8. Matsuura N, Konishi J, Harada S, et al. 1989 The prediction of thyroid function in infants born to mothers with chronic thyroiditis. Endocrinol Jpn. 36:865-871.

9. Iida Y, Konishi J, Kasagi K, et al. 1987 Inhibition of thyrotropininduced growth of rat thyroid cells, FRTL-5, by immunoglobulin G from patients with primary myxedema. J Clin Endocrinol Metab. 64:124-130.

10. Brown RS, Keating P, Mitchell E. 1990 Maternal thyroid-blocking immunoglobulins in congenital hypothyroidism. J Clin Endocrinol Metab. 70:1341-1346.

11. Southgate K, Creagh F, Teece M, Kingswood C, Smith BR. 1984 A receptor assay for the measurement of TSH receptor antibodies in unextracted serum. Clin Endocrinol (Oxf). 20:539-543.

12. Blizzard RM, Chandler RW, Landing BH, Pettit MD, West CD. 1960 Maternal autoimmunization to thyroid as a probable cause of athyrotic cretinism. N Engl J Med. 263:327-336.

13. Libert F, Lefort A, Gerard C, et al. 1989 Cloning, sequencing, and expression of the human thyrotropin (TSH) receptor: evidence of binding of autoantibodies. Biochem Biophys Res Commun. 165:1250-1255.

14. Nagayama $Y$, Wadsworth HL, Russo D, Chazenbalk GD, Rapoport B. 1991 Binding domains of stimulatory and inhibitor thyrotropin (TSH) receptor autoantibodies determined with chimeric TSHlutropin/chorionic gonadotropin receptors. J Clin Invest. 88:336340 .

15. Kosugi S, Ban T, Akamizu T, Kohn LD. 1991 Further characterization of a high affinity thyrotropin binding site on the rat thyrotropin receptor which is an epitope for blocking antibodies from idiopathic myxedema patients but not thyroid stimulating antibodies from Graves' patients. Biochem Biophys Res Commun. 180:11181124.

16. Cho BY, Shong YK, Lee HK, Koh C-S, Min HK. 1989 Inhibition of thyrotropin-stimulated adenylate cyclase activation, growth of rat thyroid cells FRTL-5, by immunoglobulin $G$ from patients with primary myxedema: comparison with activities of thyrotropin-binding inhibitor immunoglobulins. Acta Endocrinol (Copenh). 120:99106.

17. Kraiem Z, Lahat N, Glaser B, Baron E, Sadeh O, Sheinfeld $M$. 1987 Thyrotrophin receptor blocking antibodies: incidence characterization and in-vitro synthesis. Clin Endocrinol (Oxf). 27:409-421.

18. Takasu N, Mori T, Koizumi Y, Takeuchi S, Yamada T, 1984 Transient neonatal hypothyroidism due to maternal immunoglobulins that inhibit thyrotropin-binding and post-receptor processes. J Clin Endocrinol Metab. 59:142-146.

19. Zakarija M, McKenzie JM. 1983 Pregnancy-associated changes in the thyroid-stimulating antibody of Graves' disease and the relationship to neonatal hyperthyroidism. J Clin Endocrinol Metab. 57:1036-1040.

20. National Committee for Clinical Laboratory Standards. 1985 Blood collection on filter paper for neonatal screening programs; tentative standard. NCCLS publication LA4-T. Villanova: NCCLS; pp 163-182.

21. Zakarija M, McKenzie JM, Hoffman WH. 1986 Prediction and therapy of intrauterine and late-onset neonatal hyperthyroidism. J Clin Endocrinol Metab. 62:368-371.

22. Cheron RG, Kaplan MM, Larsen PR, Selenkow HA, Crigler Jr JF. 1981 Neonatal thyroid function after propylthiouracil therapy for maternal Graves' disease. N Engl J Med. 304:525-528. 